\title{
Volatile compounds in noni (Morinda citrifolia L.) at two ripening stages
}

\author{
Compostos voláteis em noni (Morinda citrifolia L.) em dois estágios de maturação
}

\author{
Jorge Antonio $\mathrm{PINO}^{1 *}$, Eliosbel MÁRQUEZ1 ${ }^{1}$ Clara Elizabeth QUIJANO², Déborah CASTRO³
}

\begin{abstract}
The volatile components of noni at two ripening stages were isolated by headspace solid-phase microextraction using $65 \mu \mathrm{m}$ Polydimethylsiloxane-Divinylbenzene (PDMS/DVB) fibers and analyzed using GC/MS. Both maturation stages had several compounds in

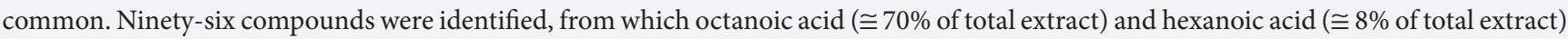
were found to be the major constituents. Due to noni maturation, octanoic acid, decanoic acid and $2 E$-nonenal decreased their concentrations, while some esters (methyl hexanoate, methyl octanoate, ethyl octanoate and methyl $4 E$-decenoate), which their fruity odor notes, increased their contents. Two unsaturated esters, reported for the first time in this fruit, 3-methyl-3-buten-1-yl hexanoate and 3-methyl-3-buten-1-yl octanoate, significantly decreased their concentration in the ripe to over-ripe fruits.

Keywords: noni; Morinda citrifolia; Rubiaceae; volatile compounds; HS-SPME; GC-MS.
\end{abstract}

\section{Resumen}

Los compuestos volátiles del noni en los dos estados de madurez se aislaron mediante microextracción en fase sólida por headspace con fibras de $65 \mu \mathrm{m}$ Polidimetilsiloxano-Divinilbenceno (PDMS/DVB) y se analizaron por cromatografía de gases/espectrometría de masas. Ambos estados de madurez poseen numerosos constituyentes en común. Se identificaron 96 compuestos, de los cuales el ácido octanoico ( $\cong 70 \%$ del extracto total) y ácido hexanoico ( $\cong 8 \%$ del extracto total) fueron los componentes mayoritarios. Debido a la maduración del noni, el ácido octanoico, ácido decanoico y $2 E$-nonenal disminuyeron su contenido, mientras que algunos ésteres (hexanoato de metilo, octanoato de metilo, octanoato de etilo y $4 E$-decenoato de metilo), con sus olororosas notas frutales, incrementaron la concentración. Dos ésteres insaturados, reportados por primera vez en esta fruta, hexanoato de 3-metil-3-buten-1-ilo y octanoato de 3-metil-3-buten-1-ilo, disminuyeron significativamente su concentración al pasar la fruta del estado maduro al sobremaduro.

Palabras clave: noni; Morinda citrifolia; Rubiaceae; compuestos volátiles; HS-SPME; GC-MS.

\section{Introduction}

Morinda citrifolia L. (Rubiaceae), commonly known as noni, is a plant typically found in the Hawaiian and Tahitian islands. It is believed to be one of the most important plants brought to Hawaii by the first Polynesians (ROSS, 2001). Different parts of the tree, including the fruit, have been traditionally used as folk remedy for many diseases such as diabetes, hypertension, and cancer (SANG et al., 2002; CHAN-BLANCO et al., 2006; POTTERAT; HAMBURGER, 2007). The consumption of the juice for health benefits has seen a tremendous growth worldwide. The plant is a small evergreen tree with large bright green elliptical leaves. The fruit results from coalescence of the inferior ovaries of many closely packed flowers, it has a smooth surface and many polygonal sections. The immature fruit is green. As it matures the fruit becomes whiter in colour, and unless it is harvested at this stage, it simply falls to the ground. As it ripens, the fruit has a very pungent smell, similar to the odor of blue vein cheese and its taste is sour.

There are two main methods used to produce noni juice. In the traditional method, the fruit is collected when it is beginning to ripen and placed in a container for several weeks.
At the end of this time a large percentage of the over-ripe fruit simply disappears into the juice; the residual fruits are mashed into a puree, and the juice is filtered to remove any remaining sediment. The dark brown juice is then ready for use. In another processing method, the mature fruit (light amber colour) is pressed and the resulting juice becomes the finished product (RUSSELL, 2000). Although the noni fruits have been used as a food, very few reports on their chemical composition are available (WANG, 1999; ROSS, 2001; KAMIYA, 2004; CHANBLANCO et al., 2006; POTTERAT; HAMBURGER, 2007), all of them related with the non-volatile components. In this study, 51 volatile compounds of the ripe fruit were isolated and quantified by solvent extraction (FARINE et al., 1996), and 24 volatile constituents were identified by HS-SPME-GC-MS using a PDMS fiber from commercial juices (LACHENMEIER et al., 2006).

Solid-phase microextraction (SPME), developed in 1989 by Pawliszyn, is a rapid, direct, inexpensive, and efficient technique for sampling different matrixes (PAWLISZYN, 1997, 1999). SPME is a multi-analyte extraction technique that requires no

Recebido para publicação em 4/4/2008

Aceito para publicação em 7/7/2009 (003353)

${ }^{1}$ Instituto de Investigaciones para la Industria Alimenticia, Carretera al Guatao km 31², La Habana 19200, Cuba, E-mail: jpino@iiia.edu.cu

${ }^{2}$ Departamento de Química, Facultad de Ciencias, Universidad de los Andes, Cra. $1^{a}$ Este N 18-A-10 Edif. (Q-826), Bogotá, Colombia

3 Instituto Finlay, Ave 27, Marianao, La Habana, Cuba

${ }^{*}$ A quem a correspondência deve ser enviada 
solvents; it minimizes artefact formation by heat and provides linear results over a wide range of analyte concentrations in a large variety of matrixes. In the field of food aroma analysis, the headspace SPME (HS-SPME) has proved to be an advanced and efficient tool for studies on food aromas, including fruits and fruit juices (HARMON, 2002; MARSILI, 2002). In fact, SPME/GC is a convenient technique for providing the aromatic fingerprint descriptions of each analyzed fruit.

The present work is aimed at studying, using HS-SPME, the change of volatile compounds of noni fruits during ripening.

\section{Materials and methods}

\subsection{Plant material and chemicals}

Freshly harvested noni fruits, grown in Havana, were purchased from a local producer. Voucher specimens were deposited in the herbarium of the National Botanic Garden in Havana (JBN-2344-08). The fruits were selected at two maturity stages: ripe (light amber colour) and over-ripe (dark brown colour), by a commercial producer. Three groups, of ten fruits each one, were manually mashed and strained using a 200-mesh sieve. The homogenized pulp was analyzed immediately after sample preparation.

Authentic reference chemical compounds with purity figures above $98 \%$ were provided by Aldrich (Milwaukee, USA).

\subsection{HS-SPME procedure}

A manual holder (Supelco, Inc., Bellefonte, USA) and $65 \mu \mathrm{m}$ Polydimethylsiloxane-Divinylbenzene (PDMS/DVB) (Supelco, Inc., Bellefonte, USA) were used for all the experiments. This fiber was selected according to the best results for the extraction of fruit volatiles (PAWLISZYN, 1999; HARMON, 2002). For each extraction, $10 \mathrm{~g}$ of pulp (without seeds) and $20 \mathrm{~mL}$ of $20 \% \mathrm{NaCl}$ solution (to inhibit enzymatic reactions and to favour the transfer of the analytes from the aqueous solution to the headspace) were blended in a Braun MR 400 juicer for 2 minutes and then centrifuged at $3000 \mathrm{rev} / \mathrm{min}$ for 10 minutes, a procedure essentially identical to those previously used for other fruits (FALLIK et al., 2001; URRUTY et al., 2002; SERVILI et al., 2006). An $8 \mathrm{~mL}$ aliquot of the supernatant was transferred into a $15 \mathrm{~mL}$ Teflon-lined septum cap vial equipped with a tefloncoated magnetic bar. To favour the transfer of the analytes from the aqueous solution to the headspace, the solution was stirred $(200 \mathrm{rev} / \mathrm{min})$ at $40^{\circ} \mathrm{C}$. After a 10 minutes wait to reach equilibrium between the solution and the headspace, the fiber was exposed for 20 minutes in the headspace. The fiber was then removed and introduced into the injector port of the GC for desorption at $250{ }^{\circ} \mathrm{C}$ for 2 minutes, in the splitless mode. Then the split valve was opened (ratio of 1:50), but the fiber was kept in the injector for 5 minutes for cleaning.

\subsection{Gas chromatography-mass spectrometry analyses}

A Hewlett-Packard 6890 GC coupled to a HP-5973 mass selective detector was employed. An inlet of $0.75 \mathrm{~mm}$ I.D., which improves the GC resolution, was used. The carrier gas was helium $\left(1 \mathrm{~mL} \cdot \mathrm{min}^{-1}\right)$ and the injector temperature was $250{ }^{\circ} \mathrm{C}$. The analytes were separated on a HP-5MS $30 \mathrm{~m} \times 0.32 \mathrm{~mm} \times 0.25 \mu \mathrm{m}$ column (Supelco, Inc., Bellefonte, USA), kept at $50{ }^{\circ} \mathrm{C}$ for 2 minutes and then ramped to $240{ }^{\circ} \mathrm{C}$ at $4{ }^{\circ} \mathrm{C} / \mathrm{min}$ and held at the final temperature for 10 minutes. The transfer line was kept at $250^{\circ} \mathrm{C}$ and the ion source was held at $230^{\circ} \mathrm{C}$. Mass spectra were measured at $70 \mathrm{eV}$ and collected at the rate of $1 \mathrm{scan} / \mathrm{second}$ over an $\mathrm{m} / \mathrm{z}$ range of 35 to 400 . Chromatographic retention indices of separated compounds were calculated relative to a $\mathrm{C}_{8}-\mathrm{C}_{22} \mathrm{n}$-alkanes mixture.

Constituents were identified by comparing their mass spectra to those in NIST/EPA/NIH, our FLAVORLIB data base and with mass spectra of authentic standards. In many compounds, the identities were confirmed by their relative retention indices with authentic standards. Mass spectra from the literature (MACLAFFERTY; STAFFER, 1989; ADAMS, 2001) were also compared.

For each compound, quantitation was performed by measuring the corresponding peak area of the total ion chromatogram and expressed as relative (percent) areas by normalization.

The original data from triplicate analyses were transformed and processed for statistical analysis by the t-Student' test.

\section{Results and discussion}

The volatile constituents of noni fruit were obtained by HS-SPME and analyzed by GC-MS using a fused silica capillary column. The peak areas of the compounds analyzed in triplicate on the same sample showed a coefficient of variation $\leq 5 \%$.

In total, ninety-six volatile compounds were identified (Table 1), sixty-seven of them reported for the first time in noni fruit, although they are often found in other fruits (NIJSSEN et al., 1996). The use of a more polar fiber in this study enables us to isolate many polar compounds not previously found in a previous study using the non-polar PDMS fiber (LACHENMEIER et al., 2006). The presence of so many aliphatic esters in fruits of both maturity stages, mainly in the over-ripe ones, is interesting. This abundance of aliphatic esters has not been reported in previous studies (FARINE et al., 1996; LACHENMEIER et al., 2006). Alkyl esters of hexanoic and octanoic acids were the major ones in this family. All these esters have powerful fruity odor notes (ARCTANDER, 1969).

In general, although terpenes are present in small quantities in both maturity stages, their contribution to the fruit's flavor could be considerable, as in the case of limonene and linalool, which were found to possess intense citrus and flower-like odors (ARCTANDER, 1969). Interestingly, three sulphur compounds were found for the first time in noni fruit, e.g. dimethyl disulfide, dimethyl trisulfide and 3-(methylthio)-1-propanol. No nitrogencontaining volatile compounds were found.

The major volatile compounds, at both maturity stages, were octanoic acid ( $\cong 70 \%$ of total extract) and hexanoic acid ( $\cong 8 \%$ of total extract), basically the same components as those previously reported (FARINE et al., 1996), although in different 
Table 1. Volatile compounds in noni at two maturity stages (mean area \%).

\begin{tabular}{|c|c|c|c|c|c|}
\hline Compound & $\mathrm{RI}_{\exp }$ & $\mathrm{RI}_{\mathrm{st}}$ & Identification & Ripe & Over-ripe \\
\hline ethanol* & 535 & 537 & A & $0.02^{\mathrm{a}}$ & $0.02^{\mathrm{a}}$ \\
\hline acetic acid & 602 & 600 & A & $0.01^{\mathrm{a}}$ & $0.02^{\mathrm{a}}$ \\
\hline 1-butanol & 650 & 653 & A & $0.04^{\mathrm{a}}$ & $0.04^{\mathrm{a}}$ \\
\hline pentanal $^{*}$ & 701 & 706 & A & $0.01^{\mathrm{a}}$ & $0.01^{\mathrm{a}}$ \\
\hline methyl butanoate ${ }^{*}$ & 728 & 729 & A & $0.01^{\mathrm{a}}$ & $0.02^{\mathrm{a}}$ \\
\hline 3-methyl-3-buten-1-ol & 730 & 731 & $\mathrm{~B}$ & $0.02^{\mathrm{a}}$ & $0.03^{\mathrm{a}}$ \\
\hline 3-methylbutan-1-ol* & 741 & 741 & A & $0.02^{\mathrm{a}}$ & $0.01^{\mathrm{a}}$ \\
\hline 2-methylbutan-1-ol* & 744 & 743 & A & $\mathrm{t}$ & 0.02 \\
\hline dimethyl disulfide ${ }^{*}$ & 747 & 746 & $\mathrm{C}$ & 0.01 & $\mathrm{t}$ \\
\hline ethyl isobutanoate ${ }^{*}$ & 750 & 751 & A & $0.01^{\mathrm{a}}$ & $0.02^{\mathrm{a}}$ \\
\hline 2-methylpropanoic acid & 758 & 758 & $\mathrm{C}$ & $0.02^{\mathrm{a}}$ & $0.01^{\mathrm{a}}$ \\
\hline 3-methyl-2-buten-1-ol & 772 & 774 & $\mathrm{C}$ & $0.03^{\mathrm{a}}$ & $0.03^{\mathrm{a}}$ \\
\hline butanoic acid & 793 & 790 & A & $0.03^{\mathrm{a}}$ & $0.04^{\mathrm{a}}$ \\
\hline ethyl butanoate ${ }^{*}$ & 801 & 804 & A & $\mathrm{t}$ & 0.03 \\
\hline butyl acetate & 809 & 811 & A & $\mathrm{t}$ & $\mathrm{t}$ \\
\hline 3-methylbutanoic acid ${ }^{*}$ & 837 & 836 & A & 0.20 & - \\
\hline ethyl 2-methylbutanoate* & 846 & 846 & A & $\mathrm{t}$ & 0.02 \\
\hline 2-methylbutanoic acid & 862 & 860 & A & $\mathrm{t}$ & 0.16 \\
\hline 1-hexanol & 870 & 871 & A & $0.29^{\mathrm{a}}$ & $0.34^{\mathrm{a}}$ \\
\hline 3-methyl-3-buten-1-yl acetate & 888 & 885 & $\mathrm{C}$ & 0.01 & $\mathrm{t}$ \\
\hline 2-heptanone & 895 & 892 & A & $0.04^{\mathrm{a}}$ & $0.04^{\mathrm{a}}$ \\
\hline propyl butanoate ${ }^{\star}$ & 898 & 899 & A & $\mathrm{t}$ & $\mathrm{t}$ \\
\hline 3-methyl-2-hexanol* & 906 & 909 & $\mathrm{C}$ & 0.01 & 0.01 \\
\hline methyl hexanoate & 930 & 927 & A & $0.37^{\mathrm{a}}$ & $0.44^{\mathrm{b}}$ \\
\hline$\alpha$-pinene ${ }^{*}$ & 938 & 939 & A & 0.01 & $\mathrm{t}$ \\
\hline butyl isobutanoate ${ }^{*}$ & 950 & 949 & A & $0.01^{\mathrm{a}}$ & $0.01^{\mathrm{a}}$ \\
\hline benzaldehyde & 858 & 960 & A & $0.01^{\mathrm{a}}$ & $0.01^{\mathrm{a}}$ \\
\hline dimethyl trisulfide ${ }^{\star}$ & 969 & 970 & $\mathrm{C}$ & $0.01^{\mathrm{a}}$ & $0.01^{\mathrm{a}}$ \\
\hline sabinene ${ }^{*}$ & 971 & 975 & A & $\mathrm{t}$ & $\mathrm{t}$ \\
\hline 3-(methylthio)-1-propanol* & 980 & 980 & $\mathrm{C}$ & $0.01^{\mathrm{a}}$ & $0.01^{\mathrm{a}}$ \\
\hline hexanoic acid & 982 & 981 & A & $8.19^{\mathrm{a}}$ & $8.16^{\mathrm{a}}$ \\
\hline 6-methyl-5-hepten-2-one & 988 & 986 & A & - & $\mathrm{t}$ \\
\hline myrcene ${ }^{\star}$ & 993 & 991 & A & $0.03^{\mathrm{a}}$ & $0.02^{\mathrm{a}}$ \\
\hline butyl butanoate & 996 & 995 & A & $0.03^{\mathrm{a}}$ & $0.02^{\mathrm{a}}$ \\
\hline ethyl hexanoate & 998 & 998 & A & $1.02^{\mathrm{a}}$ & $1.07^{\mathrm{a}}$ \\
\hline octanal $^{*}$ & 1000 & 999 & A & $\mathrm{t}$ & $\mathrm{t}$ \\
\hline hexyl acetate ${ }^{*}$ & 1011 & 1009 & A & $\mathrm{t}$ & 0.11 \\
\hline 3-methyl-3-buten-1-yl isobutanoate ${ }^{*}$ & 1014 & 1013 & $\mathrm{C}$ & $0.03^{\mathrm{a}}$ & $0.03^{\mathrm{a}}$ \\
\hline limonene & 1030 & 1029 & A & $1.44^{\mathrm{a}}$ & $1.89^{\mathrm{a}}$ \\
\hline benzyl alcohol & 1033 & 1032 & A & $\mathrm{t}$ & $\mathrm{t}$ \\
\hline$Z$ - $\beta$-ocimene ${ }^{\star}$ & 1034 & 1032 & B & $\mathrm{t}$ & $\mathrm{t}$ \\
\hline$\gamma$-terpinene ${ }^{\star}$ & 1058 & 1060 & A & - & $\mathrm{t}$ \\
\hline acetophenone $^{*}$ & 1067 & 1065 & A & - & $\mathrm{t}$ \\
\hline 1-octanol & 1069 & 1070 & A & $-\mathrm{a}$ & $0.01^{\mathrm{a}}$ \\
\hline terpinolene ${ }^{*}$ & 1088 & 1088 & B & $\mathrm{t}$ & $\mathrm{t}$ \\
\hline 2-nonanone ${ }^{\star}$ & 1089 & 1090 & A & $0.04^{\mathrm{a}}$ & $0.02^{\mathrm{a}}$ \\
\hline propyl hexanoate & 1094 & 1094 & A & $0.01^{\mathrm{a}}$ & $0.01^{\mathrm{a}}$ \\
\hline ethyl heptanoate* & 1097 & 1098 & A & 0.01 & $\mathrm{t}$ \\
\hline linalool $^{*}$ & 1099 & 1099 & A & $0.06^{\mathrm{a}}$ & $0.09^{\mathrm{a}}$ \\
\hline nonanal $^{*}$ & 1102 & 1101 & A & $0.03^{\mathrm{a}}$ & $0.07^{\mathrm{a}}$ \\
\hline heptanoic acid & 1109 & 1108 & A & $0.07^{\mathrm{a}}$ & $0.04^{\mathrm{a}}$ \\
\hline 3-methyl-3-buten-1-yl isopentanoate & 1112 & 1113 & $\mathrm{C}$ & $0.03^{\mathrm{a}}$ & $0.03^{\mathrm{a}}$ \\
\hline
\end{tabular}

$\mathrm{t}=$ lower than $0.01 \%$, - not detected, $\mathrm{RI}_{\mathrm{exp}}=$ experimental retention index, $\mathrm{RI}_{\mathrm{st}}=$ standard or literature retention index; ${ }^{\star}$ reported for the first time in noni; Values followed by the same letter are not significantly different at $\mathrm{p} \leq 0.05$. The reliability of the identification proposal is indicated by the following: A) mass spectrum and retention index agreed with standards; B) mass spectrum and retention index agreed with the literature data; and C) mass spectrum agreed with mass spectral database. 
Table 1. Continued...

\begin{tabular}{|c|c|c|c|c|c|}
\hline Compound & $\mathrm{RI}_{\exp }$ & $\mathrm{RI}_{\mathrm{st}}$ & Identification & Ripe & Over-ripe \\
\hline 2-phenylethanol* & 1117 & 1118 & A & $0.04^{\mathrm{a}}$ & $0.05^{\mathrm{a}}$ \\
\hline methyl octanoate & 1120 & 1120 & A & $4.47^{\mathrm{a}}$ & $6.13^{\mathrm{b}}$ \\
\hline 2-ethylhexanoic acid* & 1122 & 1122 & $\mathrm{C}$ & 0.01 & $\mathrm{t}$ \\
\hline hexyl isobutanoate ${ }^{*}$ & 1150 & 1152 & B & $0.03^{\mathrm{a}}$ & $0.02^{\mathrm{a}}$ \\
\hline isobutyl hexanoate & 1153 & 1156 & B & $0.05^{\mathrm{a}}$ & $0.04^{\mathrm{a}}$ \\
\hline $2 E$-nonenal ${ }^{*}$ & 1160 & 1161 & A & $0.28^{\mathrm{a}}$ & $-b$ \\
\hline octanoic acid & 1179 & 1181 & A & $72.29^{\mathrm{a}}$ & $70.47^{\mathrm{b}}$ \\
\hline butyl hexanoate ${ }^{\star}$ & 1187 & 1188 & A & $0.75^{\mathrm{a}}$ & $0.48^{\mathrm{a}}$ \\
\hline$\alpha$-terpineol ${ }^{*}$ & 1190 & 1189 & A & $\mathrm{t}$ & $\mathrm{t}$ \\
\hline methyl salicylate ${ }^{\star}$ & 1193 & 1192 & A & $\mathrm{t}$ & $\mathrm{t}$ \\
\hline ethyl octanoate & 1199 & 1197 & A & $3.48^{\mathrm{a}}$ & $4.58^{\mathrm{b}}$ \\
\hline ethyl 2-phenylacetate* & 1246 & 1247 & A & $\mathrm{t}$ & $\mathrm{t}$ \\
\hline 3-methylbutyl hexanoate & 1255 & 1254 & B & $\mathrm{t}$ & $\mathrm{t}$ \\
\hline$\gamma$-octalactone ${ }^{*}$ & 1260 & 1261 & A & $\mathrm{t}$ & $\mathrm{t}$ \\
\hline methyl $4 E$-decenoate ${ }^{\star}$ & 1262 & 1263 & $\mathrm{C}$ & $-\mathrm{a}$ & $0.15^{\mathrm{b}}$ \\
\hline $2 E$-octenoic acid ${ }^{*}$ & 1269 & 1266 & $\mathrm{C}$ & 0.07 & - \\
\hline 2-phenylacetic acid* & 1270 & 1268 & $\mathrm{~A}$ & $\mathrm{t}$ & - \\
\hline nonanoic acid & 1271 & 1271 & $\mathrm{~A}$ & $0.04^{\mathrm{a}}$ & $0.03^{\mathrm{a}}$ \\
\hline methyl decanoate & 1321 & 1326 & A & $0.71^{\mathrm{a}}$ & $0.77^{\mathrm{a}}$ \\
\hline benzyl butanoate & 1349 & 1347 & A & $\mathrm{t}$ & $\mathrm{t}$ \\
\hline eugenol & 1356 & 1359 & A & $0.08^{\mathrm{a}}$ & $0.05^{\mathrm{a}}$ \\
\hline decanoic acid & 1373 & 1371 & A & $0.24^{\mathrm{a}}$ & $0.13^{\mathrm{b}}$ \\
\hline pentyl octanoate & 1490 & 1491 & A & $\mathrm{t}$ & $\mathrm{t}$ \\
\hline 3-methyl-3-buten-1-yl octanoate* & 1513 & 1518 & $\mathrm{C}$ & $3.20^{\mathrm{a}}$ & $1.24^{\mathrm{b}}$ \\
\hline methyl dodecanoate ${ }^{\star}$ & 1523 & 1526 & A & $\mathrm{t}$ & $\mathrm{t}$ \\
\hline benzyl hexanoate* & 1549 & 1547 & A & $0.02^{\mathrm{a}}$ & $0.02^{\mathrm{a}}$ \\
\hline butyl decanoate ${ }^{\star}$ & 1599 & 1590 & A & $\mathrm{t}$ & $\mathrm{t}$ \\
\hline hexyl 2-phenylacetate* & 1630 & 1631 & B & $\mathrm{t}$ & $\mathrm{t}$ \\
\hline 2-phenylethyl hexanoate & 1639 & 1642 & A & 0.01 & $\mathrm{t}$ \\
\hline isopropyl tetradecanoate ${ }^{*}$ & 1835 & 1830 & B & $0.01^{\mathrm{a}}$ & $0.03^{\mathrm{a}}$ \\
\hline 2-phenyletyl octanoate ${ }^{*}$ & 1838 & 1842 & B & $\mathrm{t}$ & $\mathrm{t}$ \\
\hline methyl hexadecanoate & 1920 & 1922 & A & $\mathrm{t}$ & $t$ \\
\hline
\end{tabular}

$\mathrm{t}=$ lower than $0.01 \%$, - not detected, $\mathrm{RI}_{\text {exp }}=$ experimental retention index, $\mathrm{RI}_{\mathrm{st}}=$ standard or literature retention index; ${ }^{*}$ reported for the first time in noni; Values followed by the same letter are not significantly different at $\mathrm{p} \leq 0.05$. The reliability of the identification proposal is indicated by the following: A) mass spectrum and retention index agreed with standards; B) mass spectrum and retention index agreed with the literature data; and C) mass spectrum agreed with mass spectral database.

proportions (58 and 19\%, respectively). According to their odor notes (ARCTANDER, 1969), both acids are responsible for the pronounced "rancid cheese" odor of noni fruit.

Although most of the compounds remain without changes in both maturation stages, the composition of some particular volatile compounds clearly differs in both maturation stages (Table 1). Some esters, with fruity odor notes, increased, while some compounds, mainly acids, decreased or even disappeared during ripening. The over-ripe noni fruit showed significantly higher amounts of methyl hexanoate, methyl octanoate, ethyl 
octanoate and methyl $4 E$-decenoate, while octanoic acid and decanoic acid concentrations significantly decreased. These changes probably indicate that esterification occurs during maturation, in a similar way as in other fruits (WILLS et al., 1989). Only two unsaturated esters, reported for the first time in this fruit, 3-methyl-3-buten-1-yl hexanoate and 3-methyl-3buten-1-yl octanoate, significantly decreased their concentration in the ripe to over-ripe fruits.

An unsaturated aldehyde related with lipid-degraded product, 2E-nonenal, decreased during fruit maturation. As reported for tomatoes (GAILLARD et al., 1977), the activities of several enzymes seem to change during the noni fruit ripening, especially those involved in the formation of this lipid-degraded product.

\section{Conclusions}

A total of 96 volatile components of noni at two ripening stages, 67 of them for the first time, were isolated by headspace solid-phase microextraction and analyzed using GC-MS. Both maturation stages had several compounds in common. Octanoic acid ( $\cong 70 \%$ of total extract) and hexanoic acid ( $\cong 8 \%$ of total extract) were found to be the major constituents. Due to noni maturation, octanoic acid, decanoic acid and $2 E$-nonenal decreased their concentrations, while some esters (methyl hexanoate, methyl octanoate, ethyl octanoate and methyl $4 E$-decenoate), with fruity odor notes, increased their contents. Two unsaturated esters, reported for the first time in this fruit, 3-methyl-3-buten-1-yl hexanoate and 3-methyl-3-buten-1-yl octanoate, significantly decreased their concentration in the ripe to over-ripe fruits.

\section{References}

ADAMS, R. P. Identification of essential oil components by gas chromatography/quadrupole mass spectroscopy. Carol Stream: Allured Publishing Co., 2001.

ARCTANDER, S. Perfume and flavor chemicals. Copenhagen: Det Hoffensbergske Etablissement, 1969.

CHAN-BLANCO, Y. et al. The noni fruit (Morinda citrifolia L.): a review of agricultural research, nutritional and therapeutic properties. Journal Food Composition Analysis, v. 19, n. 6-7, p. 645-654, 2006.

FALLIK, E. et al. Characterisation of "Galia" melon aroma by GC and mass spectrometric sensor measurements after prolonged storage. Postharvest biology and technology, v. 22, n. 1, p. 351-357, 2001.

FARINE, J. P. et al. Volatile components of ripe fruits of Morinda citrifolia and their effects on Drosophila. Phytochemistry, v. 41, n. 2, p. 279-298, 1996
GAILLARD, T. et al. The enzymatic breakdown of lipids to volatile and non-volatile carbonyl fragments in disrupted tomato fruits. Journal of the Science of Food and Agriculture, v. 28, n. 9, p. 863-868, 1977.

HARMON, A. D. Solid-phase microextraction for the analysis of aromas and flavors. In: MARSILI, R. (Ed.) Flavor, fragrance, and odor analysis. New York: Marcel Dekker, 2002. p. 75-106.

KAMIYA, K. et al. Chemical constituents of Morinda citrifolia fruits inhibit copper-induced low-density lipoprotein oxidation. Journal Agricultural and Food Chemistry, v. 52, n. 19, p. 5843-5848, 2004

LACHENMEIER, K. et al. Authentication of noni (Morinda citrifolia) juice. Deutsche Lebensmittelrundschau, v. 102, n. 2, p. 58-61, 2006.

MACLAFFERTY, F. W.; STAFFER, D. B. The Wiley/NBS registry of mass spectral data. New York: John Wiley \& Sons, 1989.

MARSILI, R. SPME comparison studies and what they reveal. In: MARSILI, R. (Ed.). Flavor, fragrance, and odor analysis. New York: Marcel Dekker, 2002, p. 205-227.

NIJSSEN, L. M. et al. Volatile compounds in food: qualitative and quantitative data. The Netherlands: TNO-CIVO Food Analysis Institute, 1996. (v. 1)

PAWLISZYN, J. Solid-phase microextraction: theory and practice. New York: Wiley-VCH, 1997.

PAWLISZYN, J. Applications of solid-phase microextraction. Cambridge: Royal Society of Chemistry, 1999.

POTTERAT, O.; HAMBURGER, M. Morinda citrifolia (noni) fruit: phytochemistry, pharmacology, safety. Planta Medica, v. 73, n. 3, p. 191-199, 2007.

ROSS, I. A. Medical plants of the world: chemical constituents, traditional and modern medical uses. New Jersey: Humana Press, 2001.

RUSSELL, H. Island energy juice. Fruit Processing, n. 12, p. 486-488, 2000

SANG, S. et al. Chemical components in noni fruits and leaves (Morinda citrifolia L.). Washington: ACS Publications, 2002. p. 134-150 (ACS Symposium Series, 803).

SERVILI, M. et al. Relationships between the volatile compounds evaluated by solid phase microextraction and the thermal treatment of tomato juice: optimization of the blanching parameters. Food Chemistry, v. 71, n. 3, p. 407-415, 2000.

URRUTY, L. et al. Assessment of strawberry aroma through SPME/GC and ANN methods: classification and discrimination of varieties. Journal Agricultural and Food Chemistry, v. 50, n.11, p. 3129-3136, 2002.

WANG, M. et al. Novel trisaccharide fatty acid ester identified from the fruits of Morinda citrifolia (noni). Journal Agricultural and Food Chemistry, v. 47, n. 12, p. 480-4882, 1999.

WILLS, R. et al. Post harvest: an introduction to the physiology and handling of fruit and vegetables. New York: Van Nostrand Reinhold, 1989. 